\title{
Parkour, Counter-Conducts and the Government of Difference in Post-industrial Turin
}

\section{Nicola De Martini Ugolotti and Michael Silk}

Abstract: The following paper aims to offer a critical discussion of the unfolding politics of belonging and exclusion taking place in Turin's regenerating cityscape as a way to illuminate the paradoxes, tensions and daily negotiations of emerging forms of social and spatial restructuring in the post-industrial city. In developing this analysis, we engage with an integrated methodological approach that privileges the voices and experiences of about 30 young men, mostly of migrant origins and aged 16-21, practicing parkour in the city's public spaces. In addressing these issues, we focus on the participants' engagement with one of the symbols of Turin's (multi)cultural, community-oriented and creative renewal, the post-industrial urban park of Parco Dora in order to unpack the processes of inclusion/exclusion and the conduct of conduct (Rose 2000) enacted in the creation, management and use of the city's regenerating areas. Our discussion of the participants' ambivalent and contested practices in Turin's cityscape enabled us to address how these young men re-inscribe tensions, instabilities and fault-lines relational to the "selective story-telling" (Vanolo $2015,2)$ characterizing Turin's narratives of consensual transformation, post-industrial renaissance and (multi)cultural vitality. In particular, by engaging with the participants' bodily and spatial negotiations in Turin's public spaces through the lens of counter-conduct (Foucault 2007[1978]), we highlight the significance of recognising and examining partial, but productive forms of urban contestation within contemporary, pacified scenarios of urban regeneration.

Key words: Turin; Parco Dora; urban regeneration; conduct of conduct; counter-conduct; parkour

In the last two decades, a wealth of academic accounts have addressed the emergence and intersection of "creative", "smart", and "community-led" processes of urban renewal that aimed to restructure "anachronistic" post-industrial cities into technologically advanced, inclusive and 
creative global hubs attracting international tourism, talents and investments (Chatterton 2000; Binnie et al. 2006; Rutland and Ayett 2008; Huxley 2013; Vanolo 2014, 2015; Rosol 2015; Glick Schiller 2015; Mould 2015). These studies show how market revitalisation, sustainability and inclusivity have been at the core of these visions of urban rebranding. The planning and development of participatory, yet efficient, cosmopolitan and vibrant city-spaces have been represented as key elements that might bring competitive energy, as well as the cultural, symbolic and financial capital necessary to positively reposition regenerating cities in a global scenario. These contributions have also critically questioned unproblematic connections between market revitalisation, participatory governance, social/(multi)cultural inclusion and poverty alleviation that these visions supposedly enacted. Indeed, in several contexts, creative and cosmopolitan forms of city-making have continued to overlook, if not exacerbate, the stark inequalities which characterize life for an increasing number of urban dwellers (see Chatterton 2000; Semi 2004, 2015; Binnie et al. 2006; Glick Schiller 2015; Mould 2015). Others have described how "smart", "participatory" and “community-led" processes of urban renewal (Rutland and Ayett 2008; Huxley 2013; Vanolo 2014; Rosol 2015) have de facto reduced the possibilities for citizens and marginal social groups to enact transgressive politics challenging leaders', planners' and boosters' visions of urban social order. Overall, these analyses describe how a pervasive "shared" consensus on urban governance built around economic growth, urban vitality and community responsibility has been accompanied by emerging trends of depoliticisation, co-optation and commodification of subaltern and 'antagonistic' positions and relations in urban spaces, thereby altering both the meanings and boundaries of belonging and citizenship in various urban settings (see also Van Schipstal and Nicholls 2014). As such, the dismantling of the political character of dissent in urban spaces, and its increasing perception as a drain and a threat to responsible, cohesive communities, have been functional to ideals of "conflict free growth" (MacLeod 2011) that animate "creative", "smart" and "participatory" regeneration in contemporary cities. These urban processes have been therefore described as silencing, marginalising or indeed criminalising any conflicting, or "non-fitting", 
voices; legitimate, though marginal and subordinated, political subjects have instead been controlled through "arrangements of impotent participation" and consensual "good governance" (Swyngedouw 2011, 371). Alongside an active construction of consensus, and an active marginalization of dissensus (Davidson and Iveson 2015, 546), these urban visions have also witnessed an increasing use of pervasive surveillance practices on "abject" urban characters, often embodied by the figure of the undocumented migrant, the asylum seeker, the young, and/or the racialized "disruptive" other. This increasing exercise of the "exceptionalism of power" (Rose 2000) upon those constructed as "abject" urban bodies often represents the "dark side" of urban modernity (Graham 2004, 191) and has been justified by widespread imaginaries of a majority population threatened by a seamless continuum of crime, drug use, terrorism and migrants' “invasion” (Flusty 2001; Graham 2004; Coleman 2004, 2005; Silk and Andrews 2008; Manley and Silk 2014; Modest and de Koning 2016).

The discussion so far has highlighted important scholarly contributions to our understandings of contemporary scenarios of urban regeneration and aided in unpacking the consequences of such political/economic trajectories for urban dwellers' lives and civil liberties. However, as Chatterton (2000) and Flusty (2000) suggest, the lived realities of cities are seldom (if ever) univocal, and the tendencies towards a comprehensive political economic description of cities' (re)formation must be balanced by a complementary foregrounding of city-dwellers' interventions within the urban contexts they inhabit. In failing to engage and examine urban residents' mundane and (extra)ordinary daily practices and negotiations, academic research may in fact have the (unintentional) effect of reinforcing, rather than undermining, the idea that "there is no alternative" to the aforementioned dominant urban visions and processes (Davidson and Iveson 2015, 546). Thus, building on Flusty's (2000) invitation to examine the daily, partial, but productive instances of urban dwellers in city spaces, the following paper aims to offer a critical discussion of the unfolding politics of belonging and exclusion taking place in Turins regenerating cityscape. In developing this 
analysis and inspired by Lefebvre's argument that "[urban] space originates from the body" (1991, 242), we engage with an integrated methodological approach that privileges the voices and experiences of about 30 young men, mostly of migrant origins and aged 16-21, practicing parkour in the city's public spaces. Our perspective is informed by a multi- and inter-disciplinary framework that addresses bodies and urban spaces as sites where power relations and processes of uneven development are simultaneously embodied, localized, reproduced and negotiated (Foucault 1976, 2007[1978]; Lefebvre 1991; Soja 1996; Silk and Andrews 2011). Starting from this premise, our focus is on the relationship, and reciprocal constitution, of bodies, spaces and power implied in the practice of parkour in contemporary Turin. In this sense, Turin, as a city "begging for interpretation" (Soja 1989), is important in this regard. The city known as the "Italian Detroit" (Pizzolato 2008) offers in fact an emblematic site of ongoing creative, and "smart" rebranding that has been built in the last three decades on an urban narrative combining market revitalisation, cosmopolitan regeneration, and social inclusiveness (Semi 2004, 2015; Vanolo 2014, 2015). By exploring the ambivalent relationships and engagement that young traceurs (parkour practitioners) had with one of the main symbols of Turin's post-industrial renaissance, the area of Parco Dora, we illuminate the processes of inclusion/exclusion and conduct of conduct (Rose 2000) unfolding in the creation, management and use of the city's regenerating areas. Furthermore, addressing parkour as a practice wrought with contradictions indicative of current trends within Turin's urban politics, our discussion of the participants' practices aims to make visible tensions, fault-lines, paradoxes and negotiations of emerging forms of social and spatial restructuring in the post-industrial city. In so doing, we engage with and emplace Foucault's notion of counter-conduct (2007[1978]) as a way to highlight the significance of recognising and examining partial, but productive forms of urban contestation within contemporary, pacified, scenarios of "creative", "smart" and "participatory" urban regeneration.

\section{A displacing perspective on the regenerating city: parkour in Turin}


The physical practice on which we focus - and which indeed was the focus of the participants (traceurs) in this study - is thus of particular relevance for the issues discussed in this paper. Parkour can be considered as a discipline that involves a dynamic engagement and a bodily adaptation to the urban environment (Loo and Bunnell 2017). Traceurs traverse uneven urban terrains by running, jumping, climbing, and vaulting across, through and beneath obstacles in the urban landscape with the aim to go from one point of the city to another in the least number of movements possible. The name "parkour" derives from the expression parcours du combatant (fighter's tracks), a training method developed by George Hebert for the French colonial army in the early twentieth century to develop soldiers' ability to move and fight in the jungles of Southeast Asia (Atkinson 2009). Employed several decades on by firefighters in France, this training method was subsequently "poached" by groups of young people of migrant and working-class origins in the suburbs of Paris in the late 1980s (Stapleton and Terrio 2012). According to the recognised founders of the discipline, David Belle and Sebastien Foucan, the main motivation to practice and develop parkour was the lack of activities and opportunities for entertainment available for them and young people in general in their towns (Fuggle 2008). As underlined by Fuggle (2008), although these young men were not confronted by the same threats and pitfalls of the jungles of Southeast Asia, they nevertheless re-claimed a once-military technique in order to navigate and escape the symbolic and physical violence, exclusion and hostility imbued in the landscapes they daily lived (see also Stapleton and Terrio 2012). As such, Fuggle (2008) argued that, through developing parkour, these young men were able to transform the "concrete" urban jungle into a playground, therefore "making accessible and traversable that which had previously excluded them" (Fuggle 2008, 208). Reading parkour in this way is of particular relevance given the war-like imaginaries and interventions that have concretely shaped past and contemporary cityscapes, from processes of urban planning to emerging surveillance orientations (see Flusty 2001; Graham 2004; Manley and Silk 2014). In particular, city-dwellers' tactical re-appropriation of what were originally military techniques and spaces, as means to navigate, negotiate and (temporarily) displace current 
forms of urban organization and surveillance, are of importance for our understandings of urban spaces and processes (see also Garrett 2014). Further, our focus on parkour can enable us to ferret out the paradoxes and tensions embedded in inclusive and community-oriented forms of urban regeneration. While early academic studies of parkour framed the discipline predominantly in terms of "subversive resistance to oppressive city space" (Stapleton and Terrio 2012, 19), recent contributions have addressed the discipline as an ambivalent and contested site for both challenging and practicing “creative” forms of urban governance (Mould 2015; Loo and Bunnett 2017; De Martini Ugolotti, 2017). Such processes are evident in Turin, where the discipline's ongoing process of structuring and institutionalisation (see Ferrero Camoletto et al. 2015) has facilitated its incorporation in the city-sanctioned vocabulary of cosmopolitan, community-oriented and vibrant regeneration. However, parkour communities in Turin are (currently) far from homogeneous and contain diverse and sometimes contrasting visions about what the discipline is and should be. In particular, in this study we worked with groups of disenfranchised young men who only occasionally engaged with the more structured parkour organizations, and the purpose-built spaces and events that were emerging as part of the discipline's progressive institutionalisation in Turin and elsewhere. These young traceurs joined informal crews which trained in the city's public spaces, and often described their engagement in parkour as a consequence of their marginal socioeconomic status and lack of affordable leisure opportunities, rather than as a conscious, deliberate choice for a specific sporting/leisure activity. Significantly, the diverse parkour groups that animated Turin's "scene" did not frame their differences in terms of status, class or ethnic belonging, but rather in terms of the various engagements they had with the discipline, its aims and meanings. These elements of (peaceful) contention over what parkour is, means and does for traceurs in Turin highlighted an under-represented feature in the literature, where often the discipline is addressed as embodying a uniform and normalised ethos, despite the recognised lack of coherent definitions defining the practice (see Fuggle 2008, Mould 2015). Thus acknowledging the inherent ambivalence of the discipline, we focused on participants' engagement with parkour in 
Turin's cityscape as a multifaceted prism revealing the fault lines of the city's contemporary processes of urban and social regeneration, and the disputed and partial consensus about the city's urban renewal.

\section{Methodology}

To illuminate the politics of belonging and exclusion taking place in Turin through the participants' practice of parkour, we deployed an integrated methodological approach. Over an 18-month data collection period, we utilised a robust range of qualitative methods that involved: i) ethnographic observations and participation in daily parkour trainings with participants in Turin's public spaces; ii) interviews (24) and focus groups (3); iii) visual methodologies, including photo elicitation (Rose 2014; Y'ien 2013); iv) co-creation and co-production with respondents of a 32-minute documentary film, and v) analysis of policy documents, media reports and websites related to Turin's urban renewal. This integrated, multi-method approach enabled us to combine an ethnographic perspective taking place 'down below,' on the sidewalks, street corners and back lots of the cityscape with an analysis of early $21^{\text {st }}$ century Turin political economy. By "starting with the particular, the detail, the scrap of ordinary or banal existence", in our case an empirical data set centred on the participants' practice of parkour in Turin, we then worked "to unpack the density of relations and of intersecting social domains that inform it" (Frow \& Morris 2000, 354). Building on this robust data set, this analysis aims to advance understandings of how physical practices enacted by disenfranchised young men act to navigate and negotiate the paradoxes and fault lines of the city's material and discursive re-branding.

The methodological approach enabled flexibility, allowing us to adapt and address the informal, fluid characteristics of the contexts where the research took place, and to engage with the participants' creativity and preferences in choosing the means and occasions they considered 
appropriate to become involved in the research. This crystallized (Richardson and St. Pierre 2005) methodological perspective enabled us to generate a rich, sensory (Pink et. al. 2010), multifaceted and unique corpus of empirical data, which allowed us to engage with the multiplicity of the participants' embodied experiences, inscribed on their body and urban spaces through power and discourse, and negotiated through daily practice.

The participants in the study were approximately thirty in number, aged 16-21. Parkour practice in Turin's public spaces was male-dominated ${ }^{\mathrm{i}}$, and we seldom met female traceuses training in public spaces during the research. As such, this article offers a gendered perspective on the reciprocal constitution of bodies, spaces and power in Turin, as the data and discussion refer only to the practices, experiences and negotiations of disenfranchised young men in Turin's public spaces. The majority of participants were committed traceurs with various levels of experience. Most of them were of migrant background, their families originating from diverse countries from Eastern Europe, Northern and Western Africa and South America. Only two of the participants could be considered as 'ethnically Italian'. Despite a diversity in legal status (as legal residents or Italian citizens) and origins, it can be argued that participants shared a common condition as young people living at the margins of Turin's social and spatial redevelopment, as we will explain further in the following sections. Participants' names in this paper are anonymized to protect their privacy (as per ethical protocol), with the exception of a small number of excerpts transcribed from the above-mentioned documentary that are publicly available.

\section{To be young, gifted, and disenfranchised in a rebranding city}

"Turin could be the blueprint for the post-industrial city of the future" (The Guardian, July 27, 2015)

"Turin seems to me as if it is made for those who like to spend their free time in the 
malls, gyms, clubs, or restaurants spread around the city... for those who for one reason or another don't like, or can't do all these things, there is neither much, nor place..." (Karim, 21 years old, documentary excerpt)

Similar to other post-industrial cities in the Western hemisphere, the core of Turin's urban economy has been moving from the manufacturing sector to the production and consumption of cultural products and cosmopolitan imaginaries in the last three decades (Semi 2004, 2015; Vanolo 2015). This ongoing process, which was enabled, justified and accelerated by the hosting of the 2006 Winter Olympic Games and its controversial legacy, has implied a drastic reshaping of the "Italian Detroit" (Pizzolato 2008). The rebranding of the "city that looked like a factory" (Bagnasco 1986) into an inclusive, multicultural hub of "knowledge, culture, and innovation" (Urban Centre 2016) therefore materialized in a series of radical spatial and social transformations that involved the city centre and the industrial periphery alike.

Since the end of the 1990s, the most visible and celebrated result of this urban renewal process has been the regeneration of neighbourhoods (including the "Quadrilatero Romano", "San Salvario", "Vanchiglia") where the city's creative classes could reside, meet up, socialize and consume, as well as the development of a (trans)cultural identity simultaneously place-bound and global (Sigler and Wachsmuth 2015). The regeneration of central and more peripheral city spaces has often been mobilized through multicultural and cosmopolitan images and narratives that centred on ethno-chic boutiques and bistros, as well as internationally renowned events and fairs. Commenting on Turin's urban renewal, Schmoll and Semi (2013) have suggested this process of urban rebranding can be seen as a form of "multiculturalism from above": an institutional promotion and celebration of diversity that provides a "certain kind" of visibility for (post)migrant communities; one that relies mainly on the most fashionable, consumable and less challenging aspects of multicultural contexts (such as food, clothing, music/dances, etc.). 
Turin's own global ambitions thus found physical and material expression through (g)locally (Robertson 1995) shared territories (e.g. multicultural festivals, gentrified neighbourhoods, postindustrial districts "reclaimed" as cultural hubs) where encounters with difference are both enabled and constrained by ethnic restaurants, import stores and/or architectural forms. However, the valorisation of essentialised "other" foods, cultures, practices and bodies in specific manners, spaces and times does not necessarily facilitate (post)migrant communities, minorities and marginalised social groups' full civic membership. Rather, such sanitized images of urban (multi)cultural vitality_a "pleasant diversity" (Silk and Andrews 2008) — can serve to accentuate the distinction of regenerated, vibrant urban spaces from other(ed) urban areas and communities that lack the 'desired' characteristics of "otherness" and are instead defined by their segregating difference, be it poverty, ethnicity, religion or a combination of such differentiating factors (Glick Schiller 2015; Manley and Silk 2014). Indeed, despite its celebration of inclusion and desire for diversity, Turin's (multi)cultural rebranding appears instead to have produced exclusionary dynamics in the participants' daily lives and trajectories, by drawing symbolic but effective boundaries between acceptable and "non-acceptable" difference (Ley 2004):

"The fact is that people in this city will clap at me when I perform on a stage in some random club or event, but they will hold tight their bags and phones if we cross our path anywhere else" (Ricardo, 21 years old)

As we finish training in a public area in South Turin, Abdelrazak mentions that on his way home he would like to go check a group of his friends who are performing [parkour] for an urban clothing promotional event. I ask him how it would feel to be called to perform in commercial and promotional events in public areas where he is sent away so many times by “concerned" shopkeepers and residents (as it happened today to us, by the way). Abdelrazak explains that it might be helpful to show a different image of them, so that people would not always react as they did today... after few seconds 
though, he adds "Although I'd feel a bit like an obedient puppy, you know, one that does what is said, but can be sent away for no reason" (Fieldnotes, May 28, 2014).

Ricardo and Abdelrazak offered accounts suggestive of how membership in Turin's public life appeared contingent upon the capacity of their bodies and practices to reflect and contribute to a vision of a city attracting residents and tourists "of the right type" (Harvey 2001). A number of authors have discussed how civic membership in regenerating cities seems to be increasingly revolving around urban residents' capacity to contribute to a city's economic and (multi)cultural vibrancy; either through the pro-active normalisation of "consumption as citizenship" (Coleman 2005; Silk and Andrews 2008; Paton et al. 2013), or the enforcement of an ethos of "deservingness" that (re-)defines the "right to the city" for minorities and antagonistic, political communities (Van Schiptal and Nicholls 2014). Indeed, the paradox of Turin's rebranding seems to be that to successfully accomplish and legitimate the development of a global hub of "culture, tourism and innovation" (Urban Centre 2016), the differences of the classed, ethnic, (sub)cultural "other" are constructed simultaneously as necessary and threatening for the success of the urban regeneration project; the latter scenario being evoked and associated with images of incompatible (cultural) difference, and “disruptive" uses of space (De Martini Ugolotti and Moyer, 2016).

Fig. 1 "A local police officer warns away the research participants from a public area where they are practicing parkour. Turin, $14^{\text {th }}$ April, 2015. Photo by Samba"

However, and perhaps in contrast to other processes of urban renewal, the management, control, and selective inclusion of specific bodies and practices within Turin's renewing cityscape has not only been enacted through a securitisation of regenerated urban areas (Flusty 2001; Graham 2004; Coleman 2004, 2005; Silk and Andrews 2008) and processes of creative destruction (Harvey 2008) that paved the way for the normalisation of (semi)public spaces of consumption. Rather, contemporary processes of inclusion and exclusion and the definition of (non)acceptable difference seem to gravitate and coalesce in contemporary Turin around a widespread, progressive "common good" narrative. This pervasive urban ethos is endorsed and enacted by an array of actors (from 
cultural entrepreneurs to local businesses, institutions, and public-private partnerships) engaged in a "participatory" process of urban regeneration combining social and economic cohesion with the rebranding of local areas (De Martini Ugolotti, 2017). However, as Bolzoni (2018) underlines, an ethos of "community empowerment", "cohesion" and "participation" is not sufficient per se to guarantee the enactment of more democratic and just processes of decision making in the creation, management and use of regenerating urban spaces.

It is here where the practice of parkour can be most illuminating; the discipline's ambivalence and capacity to cut across definitions of what is (il)legitimate and (un)desirable in Turin's regenerating cityscape offers in fact a unique perspective on how the city's progressive and "shared" rebranding produced specific identifications, delineated boundaries and disciplined the meaning and uses of public spaces, and of the bodies attending them. One particular site emerged from the empirical data as an emblematic space that emplaced these ambivalent and apparently contradictory processes: the recently inaugurated area of Parco Dora. The subsequent section thus centres on the social practices and relationships that Parco Dora enabled and constrained within and around its area, exemplifying the spatial practices and rationalities of the "conduct of conduct" (Rose 2000; Rosol 2015) enacted in Turin's cityscape.

\section{Parco Dora, parkour and the government of difference in regenerating Turin}

Emilio and the others arranged to meet me [De Martini Ugolotti] at the "play area" of Parco Dora (a children-families' playground located within the Ex-Vitali area) "it's easier to find each other there", Bogdan tells me. Indeed, the group that trains and meets at the play area is already lively when I arrive; about twenty young men, and few young women, joke, smoke, play cards and train (only the young men) using the available architecture (the walls surrounding the play area, a swing, a concrete platform, the pillars that characterise the park). The other spaces that the traceurs use within Parco 
Dora are a series of low concrete platforms (to try jumps), some dilapidated walls, and occasionally the surrounding green areas, especially when they find old mattresses by the nearby garbage bins. The group scatters and comes together few times during the afternoon, but Dragan and Lucio seem impatient to go elsewhere ...” (Field-notes, May 2014)

"I found out about this place [Parco Dora] soon after they opened it [in 2011], a friend of mine told me about this place [...] one day we see here a group of guys jumping, and since we did more or less the same thing amongst ourselves, we went and told them "we want to try to jump as well" [...] now we don't need to send each other texts to give us appointments, we are always here" (Cosmin, 21 years old, documentary excerpts)

Fig. 2 “The "ex-Vitali” area of Parco Dora. 19 $9^{\text {th }}$ June 2015. Photo by: Nicola De Martini Ugolotti”

Fig. 3 "Training and chatting at the ex-Vitali "play area". 16" July 2015. Photo by: Ciro Quaranta”

Parco Dora $\left(456.000 \mathrm{~m}^{2}\right)$ is located at the centre of one of Turin's most important redevelopment initiatives, the Spina 3 (Comitato Parco Dora 2015). The park, inaugurated in 2011 for the $150^{\text {th }}$ anniversary of the unification of Italy, arguably resuscitated an area that, until the early 2000s, was dominated by a complex of manufacturing plants in varying states of abandonment and disrepair. Replaced with open spaces, Parco Dora provides to the surrounding, renewed neighbourhoods a "green lung" alongside a freely accessible, state-of -the-art "industrial archaeology" complex encompassing green areas and flowerbeds and a multifunctional space of 12,000 square metres (the Ex-Vitali area). Moreover, the area of the park connects two residential and commercial complexes built as part of the Spina 3 economic and social development plan, as well as three different neighbourhoods, previously separated by the industrial district (Comitato Parco Dora 2015; Cianfriglia and Giannini 2017). The re-generation of Parco Dora was unanimously hailed by media, local leaderships and 
cultural entrepreneurs as the symbol of the transformation of a city "closing its factories and re-discovering other vocations" (La Stampa, May 3, 2011). The post-industrial park can also be considered as the flagship of Turin's emergent "smart" approach to urban governance (Vanolo 2014), one based on cost-effective, participatory and community-oriented urban management operated by private-public partnerships, in this case, "Comitato Parco Dora". As "an instrument of strategic action [...] answering to the strong need of care and economic and social cohesion the city expresses" (Comitato Parco Dora 2015, emphasis added) Comitato Parco Dora has managed the urban improvements and social initiatives in the park and in the surrounding regenerating neighbourhoods until $2015^{\mathrm{ii}}$. As part of its remit, Comitato Parco Dora has delivered participatory and community-oriented initiatives (i.e. community gardening, street-art workshops, "sports for all" activities), aiming to promote civic participation and social cohesion by enhancing the use of the area by various social groups (i.e. youth, families, elderly, minorities) (Comitato Parco Dora 2015). Since its inauguration, the area has symbolised Turin's multiculturalism (by hosting the Muslim community's annual prayer at the end of Ramadan), and, served as a space for the city's fashionable and cosmopolitan urban (sub)cultures (by hosting acclaimed music festivals, providing spaces and structures for practitioners of urban sports such as skateboarding, bike polo and, as mentioned, parkour). As represented by the ethnographic excerpts that opened this section, the post-industrial park, and specifically the ex-Area Vitali, represented for the traceurs an important and normalised site within the cityscape, one that provided them (and was provided for them) with the opportunity to meet, socialise and train in a buzzing and lively space that seemed to integrate peacefully a wide range of urban activities and residents. During the research however, it became evident that the participants' practices, experiences and accounts did not echo the images of vibrancy, inclusion and participation that were intended to characterise the area, and ideally the entire image of the city:

"So they [the police] said to us, well, that the place theoretically dedicated to us is there 
[Parco Dora], if you go elsewhere to train, for example behind McDonalds, they come to send you away, they issue you a fine, or threaten to issue it, and tell you that the place is always that, right? Well, if you can't come here, you can't go there, it's clear that many, especially the youngest, end up at Parco Dora" (Samba, 20 years old)

In an apparent contrast with the inclusive urban ethos characterizing public-private partnerships like Comitato Parco Dora and the regenerating spaces they managed, the participants' accounts highlighted how invisible, but powerful relationships seemed to shape their access, presence and practices in the city's public spaces. However, rather than simply "othering" the participants' bodies and practices through physical exclusion (see Lancione 2014), these power relationships seemed to be aimed at "guiding" their possibilities of conduct and (contingent) inclusion in Turin's regenerating cityscape. In this sense, and in line with the works of Huxley (2013), Rutland and Aylett (2008), and Rosol (2015), these data illuminated how a spatial conduct of conduct operated within Parco Dora and the surrounding areas, namely as a series of processes through which urban residents are encouraged to govern themselves, and others, in certain spaces and in certain ways, under the auspices of desirable yet vacuous semantics such as "community", "participation" and "cohesion":

If you ask me why we are sent away so many times from almost all the areas we train in, I'd say it's not just because of racism or because we are considered "not from here". In my opinion it's because we go to ruin the image that people give to specific places. As for example, we train nearby the entrance of a building just outside Parco Dora, but the people living or working there think that we are ruining the image of that building by simply being there. Nobody would say shit if we were training in Parco Dora, but if we are elsewhere, basically everyone can walk up to us asking "why do you guys have to do this stuff here? Can't you just go to Parco Dora?!" (Karim, emphasis added) 
The participants' practice of parkour, normalised in Parco Dora's spaces and contested in most of the remaining city, therefore illuminated the consequences and fault-lines of the creation of planned-spontaneous, apparently consensual and pacified urban areas, oriented to an abstract, and to some extent deceptive, idea of "common good": a cohesive "we" where particular interests, and practices, are disqualified (Rosol 2014, 2015; Davidson and Iveson 2015).

As Fainstein $(2000,457-461)$ argued, in a context where action is only legitimate when it benefits everybody, even the already powerful or privileged, socially marginalized groups cannot use their most important political tool: the contested use of space for their specific needs and claims (Rosol 2015, 260). As such, through a supposedly "shared" and consensual vision, specific voices, bodies and practices were being both valorised and contained in the Parco Dora area, while also being excluded from other public spaces:

"Everywhere we go to train, at some point someone comes to bother us, it can be the man at the window telling us to get a job, the elderly who call the police because they think we are thieves, or vandals... even guys of our age often come to us and ask us 'why did you guys come to do your stuff here?'“ (Abdelrazak, 19 years old)

“After hearing so often, 'you can't stay here, you can't go there', 'your place is Parco Dora', it feels like they're just trying to contain us" (Marcos, 20 years old, emphasis added).

Interestingly, the spaces of Parco Dora seemed very distant from the militarised areas and interdictory spaces created by planners and developers to "systematically exclude those adjudged unsuitable and even threatening, people whose class and cultural positions diverge from the builders and their target markets" (Flusty 2001, 659). Compared with other "spaces 
of play" discussed in the literature and characterised by the deployment of surveillance and control "to extirpate the spontaneous, the unpredictable $[\ldots]$ dissident, alien cultural practices and the insufficiently affluent from the built environment" (Flusty 2001, 659-661; see also Graham 2004; Coleman 2004, 2005; Silk 2007; Silk and Andrews 2008), the porous spaces of Parco Dora seemed instead to successfully incorporate "diverse" urban bodies and practices (from djs, traceurs and skaters to cultural/religious organizations, families and youth in general) in the symbol of a rebranding, vibrant and inclusive city.

Fig. 4 "Handstands competition at Parco Dora ex-Vitali area. $6^{\text {th }}$ October 2016. Photo by: Razvan"

However, whilst Parco Dora appeared to resemble a spontaneous, buzzing, yet safe space coconstructed by different users, in which parkour and a variety of practices were normalised and celebrated, the data suggested that young people also ambivalently conceived of it as a container of diversity. With Peck and Tickell (2002), we can see the spaces of Parco Dora as emblematic of a discursive armoury rolled out under the rhetoric of reform which operates to fashion new urban subjectivities, bind place branding and market revitalisation with social good, socialise individualised, responsible subjects and discipline those perceived to be, or positioned as, non-compliant. In this sense, a range of urban actors (from local institutions, to public-private partnerships and cultural entrepreneurs, to businesses and groups of "concerned" residents) have contributed to an emergent spatial order that renders specific urban bodies simultaneously visible for celebration and containment. The rationalities ${ }^{i i i}$ underpinning this emerging government of difference seem to ultimately refer to an emerging urban vision which legitimates (moral) responsibility and investment in a supposedly consensual image of the city to address a series of urban problems: the restoration of vast post-industrial areas, the necessity to rebrand urban peripheries as cohesive, vibrant, and productive, the management of increasing social tensions in a city that, despite its regeneration narratives, is currently the poorest in the industrial North of Italy, with an 
unemployment rate of almost $41 \%$ in the $15-25$ age range (La Stampa, October 8, 2017).

In celebrating, accumulating and making visible and palatable a vast array of urban and cultural practices, Parco Dora's “ordered disorder" (Coleman 2005, 135) effectively contributed both to the city's rebranding as a vibrant (multi)cultural hub and to the resuscitation and pacification of a part of the city that arguably represented Turin's rebranded image. Yet, the ethnographic material suggested that in celebrating as much as differentiating specific urban bodies and practices, the area of Parco Dora, as the elective (and normalised) urban space where difference is legitimated and accumulated in contemporary Turin, reinforced an urban vision which served to delimit the possibilities of locating the city as the site of encounters, conflicts and sociabilities, or as a site of plural, democratic politics (Mitchell 1995).

\section{"There's a part of us on any of these walls": Parkour and counter-conducts in Turin}

"It all comes to that, and it's very simple: You can give us, or keep us in as many places you want, but we'll keep looking for more..." (Alessandro, 20 years old)

Our 18-month long engagement with the traceurs in the study allowed us to illuminate not only the diffused and pervasive forms of conduct of conduct within and around the spaces of Parco Dora, but also the traceurs' situational negotiations of Turin's emerging government of difference. As suggested in the previous section, the participants' uses of the spaces of Parco Dora reinforced on one hand the processes that reproduced their selective and contingent inclusion in Turin's regenerating cityscape. However, the participants' practice of parkour beyond the spaces of the park also highlighted their ambivalent and irreverent negotiations of the same processes, and served to re-inscribe cleavages and instabilities within 
Turin's "selective story-telling" (Vanolo 2015, 2) of a "shared" and consensual urban renewal.

As such, the emplaced physicality of parkour-enacted in urban peripheries and shadows as opposed to designated spaces-offered a conduit into the (in)visible negotiations demonstrated by disenfranchised young men to make sense of, and indeed understand their own positioning and sense of be(long)ing within Turin's emergent spatial and social order. These situational, but productive negotiations were not grounded in any attempts to deny or overturn the power dynamics in which they were immersed. Rather, these negotiations emerged from a tactical usage of the cracks and fissures of Turin's emerging urban organisation. As emerged from the participants' accounts, the transformation of driveways, parking lots, pedestrian pathways and flyovers into open-air gyms and playgrounds meaningfully enabled these young men to shape their sense of self and place in the city:

"Take the driveway at that building behind the McDonalds. For passers-by it is just useless, just a driveway, or maybe just part of the background, while we spend hours jumping, slamming, sliding on it, there's a part of us on any of these walls" (Marcos, 20 years old, emphasis added)

Fig. 5 "Parkour training at a multi-level parking driveway. Turin, $28^{\text {th }}$ October 2016. Photo by Hicham"

This situational re-appropriation of the scraps of Turin's urban spaces represented meaningful "revolts of conduct" (Foucault 2007[1978], 196), or counter-conducts, that form part of "the struggle against the processes implemented for conducting others" (201). Appropriating Davidson (2007), the data suggested parkour as an embodied and emplaced practice enacted by the young men in the study as a form of resistance or 
refusal; one not directed at power in the form of economic exploitation or social categorization (e.g. in relation to the participants' gendered, classed and often racialised bodies), but rather one aimed toward negotiating the domain of one's own conduct or behaviour $(2007, \mathrm{xx})$. In this sense, we can ascertain the multiple and related dimensions and domains of conduct, as the conduct of individuals, relations between individuals, and as the way in which individuals conduct themselves (Foucault 2007[1978], 193). The embodied nature of counter-conduct as a means of negotiating available modes of self-conduct was clearly expressed in the data:

“There are people who spend their lives studying, trying to understand, I don't know, philosophical things and they get it, they get who they are, what kind of person they want to be, right? And then there are people like me, and my friends, we get it through other ways ... I get it by training [parkour] ... (Marcos, 21 years old, documentary excerpt, emphasis added)

"I guess a lot of the things I realised with parkour, you know ... how not to be a dick, concerning me and others ... they have been trying to teach me these things in my family, in school ... I could not just get it the way they were doing it, but I get it when I train, and that's the main reason why I keep training now" (Reda, 19 years old, interview excerpt)

As discussed in the previous sections, the participants' engagement with parkour was initially the consequence of a lack of other opportunities afforded to them in Turin. Contrary to common readings that described traceurs as (predominantly white, male, middle-class) urban flâneurs consciously subverting the rules and boundaries of the capitalist city (Daskalaki et al. 2008; Atkinson 2009; Bavinton 2011), the disenfranchised and often post-migrant young men 
in this study described their engagement with parkour as having, at least in origin, no other rationale than a free opportunity for leisure and socialisation. Nevertheless, the frictions and conflicts that often accompanied the participants' unexpected and irreverent practice of parkour in public spaces made manifest and negotiated the invisible power relations defining what constitutes the public, how it should be used and by whom in Turin's regenerating cityscape (De Martini Ugolotti, 2015; De Martini Ugolotti and Moyer, 2016). Rather than through a "purely negative act of disobedience" (Foucault 2007[1978], 200), or an explicit and organised political claim, these negotiations centred on physical practices that enabled the participants to form and transform their sense of self and self-worth as they re-created the contours of the city :

"The aim of parkour is to go from a point A to a point B, right? So, there is no point for us to remain stuck in only one place" (Lucio, 21 years old)

Fig. 6 "Kong vault on a concrete table-tennis in a public garden. Turin, $6^{\text {th }}$ May 2016. Photo by: Karim"

Our reading of the techniques of counter-conduct utilised by disenfranchised young men through the practice of parkour points towards the intersections between the ethical and the political (Davidson 2007, xx) in their daily negotiations of Turin's emerging spatial and social order. In engaging with uses of the body and urban spaces grounded in needs of socialization, belonging and self-constitution, the participants' engagement with parkour afforded them the possibility "to think and act otherwise" (Cadman 2010, 550) both in regard to their bodies and to city spaces, and so as to disrupt the hierarchies of belonging (Back et al. 2012) and rationalities of the government of difference within and on the peripheries of Parco Dora.

Addressing participants' practices as counter-conducts affords a distinctive perspective on 
urban (micro)politics in scenarios of apparently consensual and participatory urban regeneration and helps to re-configure the dialectic of power/resistance as not only "the collisions of pre-given actors, views and interests" (Nicholls and Uitermark 2016, 5) or the realm of explicit transformative social projects. That is, in recognizing these daily negotiations for their simultaneous ambivalence and productivity, we need to ensure that we do not just value "resistances" or negotiations "that claim a pure form of equality" (ibid.). By emplacing counter-conduct in urban spaces, we are therefore able to consider and make visible the margins of negotiation of power and conduct that are constantly being made, undone and re-made by urban dwellers in the innumerable cracks and fissures that the processes of urban regeneration engender while unevenly reshaping cities.

\section{Conclusions}

This paper provided an ethnographic exploration of the unfolding politics of belonging and exclusion taking place in Turin's regenerating cityscape. Through an integrated methodological approach, we have attempted to privilege the voices and experiences of disenfranchised young men practicing parkour in Turin, aiming to make visible the paradoxes, tensions and daily negotiations of emerging forms of social and spatial restructuring in the post-industrial city. The analysis of the participants' ambivalent relationship with one of the main symbols of Turin's post-industrial renaissance, the area of Parco Dora, enabled us to discuss some of the wider consequences of Turin's ongoing process of regeneration on the city-dwellers' daily lives and trajectories. Some of these consequences related to the apparently inclusive shifts in the representation and regulation of informal (sub)cultural practices and uses of space in Turin (from parkour to street art and other forms of non-organized leisure and expression, like informal gatherings in public areas). Increasingly, these practices passed from representing controversial forms of presence and, potentially, dissent in Turin's public life, to de-politicised manifestations of urban creativity that are valorised and celebrated in specific urban contexts (like Parco Dora), while being deemed 
"disruptive" and "anti-social" in most of the remaining cityscape. The implicit risks implied in this pacified vision of creative and "shared" regeneration is the progressive redefinition of the "public" dimensions of urban spaces. These can pass from representing arenas of social relationships, practices and tensions where marginalised groups can assert their presence, needs and claims in the urban polity to pacified sites where "arrangements of impotent participation" and consensual "good governance" are performed (Swyngedouw 2011, 371). As highlighted by the participants' accounts, in this emerging, pacified and "shared" urban organization the enactment of militarised forms of urban control is nevertheless far from diminishing, but possibly only recalibrating its scope and aims. In the regenerating, inclusive cityscape of a cosmopolitan and vibrant Turin, pro-active and diffused forms of surveillance are not focussed on preserving interdictory spaces and fortified enclaves aiming to "exclude otherness" (Flusty 2001, 659). They are rather targeting those who cannot (or will not) fit, participate in and consume the emerging city image and rhetoric: the homeless, the undocumented migrant, the asylum seeker, the ambulant vendor and the "disruptive youth" engaged in improper practices and uses of the city spaces ${ }^{\mathrm{iv}}$. Building on these considerations, we contend that the stakes, meanings and effects of the participants' practices were not only relevant for the young traceurs in the study. The participants' ambivalent and situational re-appropriations enabled us to illuminate how forms of the conduct of conduct and selective inclusion operate in Turin's regenerating areas, and the ways through which the definitions of the public, community, rights, security, and ultimately of the "desirable" and "abject" bodies in the city were being re-created in the rebranding cityscape. In focusing on the participants' ambivalent relationship with the spaces of Parco Dora and the wider cityscape, our aim, however, was not limited to exploring how an emerging government of difference operated to include, exclude and distribute bodies and practices in urban spaces, according to their capacity to add (or not) to the symbolic, economic and (multi)cultural capital of the regenerating city.

By engaging with participants' bodily and spatial negotiations and emplacing counter-conducts in 
contemporary Turin, we were thus able to highlight and address forms of urban contestation which did not envision the enactment of any radically emancipatory project, but nevertheless acted to daily displace, erode and interrogate the existing governmental order of the city. In fact, the traceurs' daily, obstinate and ambivalent presence in Turin's urban spaces re-inscribed cleavages and tensions within Turin's dominant narrative of participatory and consensual urban development, and inherently challenged the neglect of conflict inspired by this urban vision. By holding power and resistance as coextensive to each other (Foucault 1980), a focus on counter-conduct allowed us to appreciate the ambivalence and fragility of the participants' daily practices and negotiations without eclipsing the inherent politics of space they conveyed. Our analytical understanding of the participants' engagement with parkour in Turin suggests ways in which urban dwellers' actively question existing urban regimes; serving to problematise and unpack processes that are portrayed as inevitable and inexorable by their advocates and proponents (as well as in certain academic perspectives). In advancing an embodied and emplaced analysis that articulates the mundane and the (extra)ordinary practices that make up life for urban dwellers to an understanding of the political economies shaping contemporary cityscapes, our modest contributions are thus twofold. First, the discussion has illuminated the processes of selective inclusion and the conduct of conduct that take place in apparently consensual and community-oriented contexts of urban regeneration, and some of the consequences that these processes have in delineating boundaries and disciplining the meaning and uses of public spaces, and of the bodies within them. Second, our approach has been able to highlight the (in)visible urban practices and negotiations that daily and actively re-imagine how urban spaces — in contextually specific locations — can be used and lived, and the ways through which they can(not) be governed.

\section{References}

Atkinson, M., 2009. "Parkour, Anarcho-Environmentalism and Poiesis.” Journal of Sport \& Social Issues. 33 (2): 169-194. 
Back, L., Sinha, S., and Bryan, C., 2012. "New Hierarchies of Belonging.” European Journal of Cultural Studies (15)2: 139-154.

Bagnasco, A., 1986. Torino un profilo sociologico. Milano: Einaudi

Bavinton, N., 2011. "Parkour, leisure and the reinterpretation of constraints." Annals of Leisure Research, 10 (3-4): 391-412.

Binnie J Holloway J Millington S and Craig Young, eds. 2006. Cosmopolitan Urbanism. London: Routledge.

Bolzoni, M., 2018. "Iniziative dal basso nella città che cambia. Riflessioni a partire dal caso di San Salvario.”. In Torino: un profilo etnografico edited by Capello, C., and Semi, G., 69-90. Milano: Meltemi.

Cadman, L., 2010. "How (not) to be governed: Foucault, critique, and the political." Environment and Planning D: Society and Space 28 (3): 539-556.

Chatterton, P. 2000. "Will the real Creative City please stand up?” City 4(3): 390-397.

Cianfriglia, L., e Giannini, S., 2017. “Accompagnare la trasformazione. Due esperienze di rigenerazione urbana sul territorio torinese: il Comitato Parco Dora sulla Spina 3 e il Comitato Urban in Barriera di Milano" in Post-fordismo e Trasformazione Urbana edited by Armano E., Dondona, C.A., and Ferlaino, F., 163-186. Torino: Ires Regione Piemonte.

Coleman R., 2004. "Images From a Neoliberal City: The State, Surveillance and Social Control." Critical Criminology 12: 21-42.

Coleman, R., 2005. "Surveillance in the city: Primary definition and urban spatial order." Crime, Media, Culture 1(2): 131-148.

Comitato Parco Dora, 2015. Il Comitato Parco Dora. https://comitatoparcodora.wordpress.com [Last access: 7 aprile 2017]

Daskalaki, M., Stara, A., and Imas, M., 2008. “The 'Parkour Organisation': Inhabitation of corporate spaces." Culture and Organization, 14: 49-64. 
Davidson A., I., 2007. “Introduction.” In Security, territory, population. Lectures at the Collège de France $1977-78$ by M. Foucault. New York: Palgrave Macmillan

De Martini Ugolotti, N., 2015. "Climbing walls, making bridges: children of immigrants' identity negotiations through capoeira and Parkour in Turin". Leisure Studies, 34 (1): 19-33.

De Martini Ugolotti, N., 2017. "We are rolling and vaulting tonight: sport programmes, urban rigeneration, and the politics of parkour, in Turin, Italy". International Journal of Sport Policy and Politics, 9(1): 25-40.

De Martini Ugolotti, N. and Moyer, E., 2016, "If I climb a wall of ten meters: Capoeira, Parkour and the politics of public space among (post)migrant youth in Turin, Italy." Patterns of Prejudice, 50 (2): 188-206.

Davidson, M., and Iveson, K., 2015. "Recovering the politics of the city: from the "post-political city" to a "method of equality" for critical urban geography" Progress in Human Geography 39(5): 543-559.

Fainstein S. 2000. "New directions in planning theory" Urban Affairs Review 35(4): 451-478.

Ferrero Camoletto, R., Sterchele, D., and Genova, C., 2015. "Managing alternative sports: new organisational spaces for the diffusion of Italian parkour." Modern Italy 20 (3): 307-319.

Flusty, S., 2000. “Trashing Downtown: Play as resistance to the spatial and representational regulation of Los Angeles." Cities 17(2): 149-158.

Flusty, S., 2001. “The Banality of Interdiction: Surveillance, Control and the Displacement of Diversity." International Journal of Urban and Regional Research 25(3): 658-664.

Foucault, M., 1976. Discipline and Punish. Harmondsworth: Penguin.

Foucault, M., 1980. Power/Knowledge: Selected interviews and other writings 1972-1977. New York: Harvester Wheat sheaf.

Foucault, M., (1978) 2007. Security, territory, population. Lectures at the Collège de France 197778. New York: Palgrave Macmillan

Frow, J., and Morris, M., 2000. “Cultural studies.” In Handbook of Qualitative Research (2nd ed.) 
edited by N. K. Denzin \& Y. S. Lincoln, 315-346.Thousand Oaks, CA: SAGE.

Fuggle, S., 2008. "Discourses of Subversion: The Ethics and Aesthetics of Capoeira and Parkour." Dance Research, 26 (2): 204-222.

Garrett, B., L., 2014. "Undertaking recreational trespass: urban exploration and infiltration.” Transactions of the Institute of British Geographers 39(1): 1-13.

Glick Schiller, N., 2015. "Diasporic cosmopolitanism: Migrant Sociabilities and City Making.” In Whose Cosmopolitanism? Critical Perspectives, Relationalities and Discontent, edited by N. Glick Schiller and A. Irving, 103-120. New York: Berghan.

Graham, S., 2004. "Postmortem City.” City 8(2): 165-196.

Harvey, D., 2001. Spaces of Capital: Towards a Critical Geography. London and New York: Routledge.

Harvey, D., 2008. "The right to the city.” New Left Review, 53: 23-40.

Huxley, M., 2013. "Historicizing planning, problematizing participation.” International Journal of Urban and Regional Research 37(5): 1527-1541.

Lancione, M., 2014. "Assemblages of care and the analysis of public policies on homelessness in Turin, Italy." City 18(1): 25-40.

Lefebvre, H., 1991. The Production of Space. Oxford: Blackwell.

Ley, P., 2004. “Transnational spaces and everyday lives.” Transactions of the Institute of British Geographers 29: 151-164.

Loo, W. B., and Bunnell, T., 2017. "Landscaping Selves Through Parkour: Reinterpreting the Urban Environment in Singapore.” Space and Culture: https://doi.org/10.1177/1206331217720073 Manley, A., and Silk, M., 2014. "Liquid London: Sporting spectacle, britishness and ban-optic surveillance." Surveillance and Society 11(4): 360-376.

MacLeod, G., 2011. "Urban politics reconsidered: Growth machine to post-democratic city?" 
Urban Studies 48(12): 2629-2660.

Mitchell, D., 1995. “The End of Public Space? People's Park, Definitions of the Public and Democracy." Annals of the Association of American Geographers 85(1): 108-133.

Mould, O., 2015. Urban subversion and the creative city. Abingdon: Routledge.

Nicholls, W., J., and Uitermark, J., 2016. “Introduction: planning/resistance.” Urban Geography 38(4): $512-520$

Paton, K., Mooney, G., and McKee, K., 2012. “Class, citizenship and regeneration: Glasgow and the Commonwealth Games 2014.” Antipode, 44(4): 1470-1489.

Peck, J., and Tickell, A., 2002. "Neoliberalizing Space.” Antipode, 34 (3): 380-403.

Pink, S., Hubbard, P., O’Neill, M., and Radley, A., 2010. "Walking Across Disciplines: From Ethnography to Arts Practice.” Visual Studies 25(1): 1-7.

Pizzolato, N., 2008. Challenging global capitalism: Labor migration, radical struggle, and urban change in Detroit and Turin. New York: Palgrave MacMillan.

Richardson, L., and St. Pierre, E., 2005. "Writing a Method of Inquiry.” In Handbook of qualitative research $\left(3^{\text {rd }}\right.$ ed.) edited by Denzin, N., K., and Lincoln, Y., S., 959-978. Thousands Oak, CA: Sage. Robertson, R., 1995. “Glocalization: Time-Space and Homogeneity-Heterogeneity.” In Global Modernities edited by Featherstone, M., Lash, S., and Robertson, R., 25-44. Sage Publications, London.

Rose, G., 2014. “On the relation between 'visual research methods' and contemporary visual culture." The Sociological Review 62(1): 24-46

Rose, N., 2000. “Government and control.” British Journal of Criminology 40(2): 321-339.

Rosol, M., 2014. “On resistance in the post-political city: conduct and counter- conduct in Vancouver." Space and Polity 18(1): 70-84.

Rosol, M., 2015. "Governing cities through participation - a Foucauldian analysis of CityPlan 
Vancouver." Urban Geography 36(2): 256-276.

Rutland, T., and Aylett A., 2008. "The work of policy: Actor networks, governmentality, and local action on climate change in Portland, Oregon” Environment and Planning D: Society and Space, 26(4): 627-646.

Schmoll, C., and Semi, G., 2013. "Shadow circuits: urban spaces and mobilities across the Mediterranean." Identities: Global Studies in Culture and Power 20(4): 377-392.

Semi, G., 2004. "Un quartiere che (si) distingue: un caso di gentrification a Torino." Studi Culturali. 1(1): 83-106.

Semi, G., 2015. Gentrification: Tutte le città come Disneyland? Bologna: Il Mulino.

Sigler, T., and Wachsmuth, D., 2015. “Transnational Gentrification: Globalisation and

Neighbourhood Change in Panama's Casco Antinguo.” Urban Studies 53(4): 705-722.

Silk, M., and Andrews, D., 2008. "Managing Memphis: Governance and Spaces of Inequality." Social Identities 14(3): 395-414.

Silk, M., and Andrews, D., 2011. "Toward a physical cultural studies.” Sociology of Sport Journal, 28 (1): 4-35.

Soja, E. W., 1989. Postmodern Geographies. New York: Verso.

Soja, E. W., 1996. Thirdspace. Journeys to Los Angeles and other real-and-imagined places.

Oxford: Blackwell.

Stagi, L., 2015. "Crossing the symbolic boundaries: parkour, gender and urban spaces in Genoa." Modern Italy, 20(3): 295-305.

Stapleton, S., and Terrio, S., 2012. "Le Parkour: Urban Street Culture and the Commodization of Male Youth Expression.” International Migration 50 (6): 18-27.

Swyngedouw, E., 2011. “Interrogating post-democratization: Reclaiming egalitarian political spaces.” Political Geography 30(7): 370-380.

Urban Center, 2016. http://www.urbancenter.to.it/?lang=en [Last accessed, 7th April 2017] 
Van Schipstal, I., and Nicholls, W., 2014. "Rights to the Neoliberal City: The Case of Urban Land Squatting in "Creative” Berlin.” Territory, Politics, Governance 2(2): 173-193.

Vanolo, A., 2014. "Smartmentality: The Smart City as a Disciplinary Strategy." Urban Studies, 51(5): 883-898.

Vanolo, A., 2015. "The image of the creative city, eight years later: Turin, urban branding, and the economic crisis taboo." Cities 46: 1-7.

Wheaton, B., 2016. "Parkour, Gendered Power and the Politics of Identity". In Women in Action Sport Cultures. Global Culture and Sport Series, edited by Thorpe, H., and Olive R. , 111-132. London: Palgrave McMillan.

Yi'En, C., 2013. “Telling Stories of the City: Walking Ethnography, Affective Materialities, and Mobile Encounters.” Space \& Culture, 17(3): 211-223.

Nicola De Martini Ugolotti is a lecturer at Bournemouth University and member of the Associazione Frantz Fanon in Turin. ndemartiniugolotti@bournemouth.ac.uk

Michael Silk is a Professor and Deputy Dean (Resesarch \& Professional Practice) in the Faculty of Management, Bournemouth University.msilk@bournemouth.ac.uk 
i For an initial discussion on gender relations in parkour, see Stagi (2015) and Wheaton (2016).

ii The Comitato Parco Dora officially ceased its activities in 2015. The network of local institutions, businesses, bank foundations, and third sector organisations that composed its board has given continuity to the participatory and community-oriented public-private management of the park and the surrounding areas under the aegis of Turin Municipality, with no significant changes to the area's governance to date (see Cianfriglia and Giannini, 2017).

iii Here we use the term rationality as given by Rose and Miller $(1992,175)$ to mean the discursive fields within which the exercise of power is conceptualised, and the moral justifications for particular ways of exercising power by various authorities, are made explicit.

iv As sanctioned by the recent approval in August 2017 of the "Minniti-Orlando" Decree Law providing "exceptional powers" to Italian cities' chief police magistrates in order to manage public spaces and migratory flows. 